\title{
PEMANFAATAN PROGRAM PEMBELAJARAN LOVAAS (ABA) DENGAN PENDEKATAN ICARE DALAM MENINGKATKAN KEMAMPUAN GENERAL LIFE SKILL ANAK AUTIS
}

\author{
${ }^{1}$ Kuntum An Nisa Imania , ${ }^{2}$ Siti Husnul Bariah \\ Program StudiPendidikan Teknologi Informasi, Fakultas Ilmu Terapan dan Sains \\ Institut Pendidikan Indonesia \\ Email: ${ }^{1}$ kuntum.27@gmail.com ${ }^{2}$ sitihusnulbariyah@gmail.com
}

\begin{abstract}
The purpose of this research is to know how to apply Lovaas method with ICARE approach to General Life Skill Child Autism. This research includes the type of literature study research by finding reference theory relevant to the case or problems found. Reference theory obtained by way of research literature study serve as the basic foundation and the main tool for research practice in the field. To obtain appropriate information in the utilization activities carried out through the activities of utilization / use of Lovaas method with ICARE approach. In general, the program objectives are as follows: (1) Student Team effort, (2) Compliance, (3) Reduced self-stimulatory, (4) Teaches the ability to simulate, (5) Introduce the other child as a model, (7) Playing independently, (8) Pre-school ability, (9) Teach self-help skills, (10) Teach social skills (11) Teaches brute and refined motor skills, (12) Teaches receptive / expressive language Abilities that have been taught are then generalizable to others and other situations.
\end{abstract}

Keywords : Lovaas Learning Program, ICARE, General Life Skill, Students with Learning Disabilities

Abstrak - Tujuan dari penelitian adalah untuk mengetahui bagaiamana penerapan metode Lovaas dengan pendekatan ICARE terhadap General Life Skill Anak Autis. Penelitian ini termasuk jenis penelitian studi literatur dengan mencari referensi teori yang relevan dengan kasus atau permasalahan yang ditemukan. Referensi teori yang diperoleh dengan jalan penelitian studi literatur dijadikan sebagai fondasi dasar dan alat utama bagi praktek penelitian ditengah lapangan. Untuk memperoleh informasi yang tepat dalam kegiatan pemanfaatan dilakukan melalui kegiatan pemanfaatan/penggunaan metode Lovaas dengan pendekatan ICARE. Secara umum, tujuan programnya adalah sebagai berikut: (1) Usaha Tim Pengajar - siswa, (2) Compliance (kepatuhan, (3) Mengurangi self-stimulatory, (4) Mengajarkan kemampuan menirukan, (5) Perkenalkan anak yang lain sebagai model, (6) berkomunikasi: (a) Berbicara, (b) Gambar, (c) Bahasa isyarat. (7) Bermain secara mandiri, (8) Kemampuan pra-sekolah, (9) Ajarkan kemampuan bantu diri, (10) Ajarkan kemampuan bersosialisasi (11) Ajarkan 
kemampuan motorik kasar dan halus, (12) Ajarkan bahasa reseptif/ekspresif. Kemampuan yang telah diajarkan kemudian digeneralisasikan ke orang-orang lain dan situasi lainnya.

Kata Kunci : Program Pembelajaran Lovaas, ICARE, General Life Skill, Anak Berkebutuhan Khusus

\section{Pendahuluan}

Pada dasarnya setiap anak berpotensi mengalami problema dalam belajar, hanya saja problema tersebut ada yang ringan dan tidak memerlukan perhatian khusus dari orang lain karena dapat diatasi sendiri oleh anak yang bersangkutan dan ada juga yang problem belajarnya cukup berat sehingga perlu mendapatkan perhatian dan bantuan dari orang lain. Anak luar biasa atau disebut sebagai anak berkebutuhan khusus (children with special needs), memang tidak selalu mengalami problem dalam belajar. Namun, ketika mereka diinteraksikan bersama-sama dengan anak- anak sebaya lainnya dalam system pendidikan regular, ada hal-hal tertentu yang harus mendapatkan perhatian khusus dari guru dan sekolah untuk mendapatkan hasil belajar yang optimal.

Pembelajaran untuk anak berkebutuhan khusus (student with special needs) membutuhkan suatu strategi tersendiri sesuai dengan kebutuhan masing - masing. Dalam penyusunan progam pembelajaran untuk setiap bidang studi hendaknya guru kelas sudah memiliki data pribadi setiap peserta didiknya. Data pribadi yakni berkaitan dengan karateristik spesifik, kemampuan dan kelemahanya, kompetensi yang dimiliki, dan tingkat perkembanganya. Karakteristik spesifik student with special needs pada umumnya berkaitan dengan tingkat perkembangan fungsional . Karaktristik spesifik tersebut meliputi tingkat perkembangan sensori motor, kognitif, kemampuan berbahasa, ketrampilan diri, konsep diri, kemampuan berinteraksi social serta kreativitasnya.

Menurut John Dewey, pendidikan diartikan sebagai suatu proses pemebentukan kecakapan-kecakapan fundamental baik secara intelektual maupun emosional ke arah alam dan sesama manusia. Agak mirip dengan pendapat John Dewey tersebut, tokoh lain J.J Rousseau mengartikan pendidikan pendidikan sebagai usaha memberi bekal yang tidak ada pada masa kanak-kanak akan tetapi dibutuhkan pada masa ia dewasa dalam bentuk kecakapankecakapan hidup. Sedangkan menurut bapak pendidikan Indonesia $\mathrm{Ki}$ Hajar Dewantara, memaknai pendidikan sebagai usaha menuntun segala kekuatan kodrat yang ada pada masa anak sebagai manusia dan sebagai anggota masyarakat supaya dapat mencapai kesempurnaan hidup. (Arif Rohman 2009: 168).

Pada jenjang pendidikan dasar yaitu: TK/RA, SD/MI, SMP/MTS lebih ditekankan pada pengembangan generik/ General Life Skills (GLS) sebagai (1) upaya mengakrabkan peserta didik dengan perikehidupan nyata di lingkungannya, (2) menumbuhkan kesadaran tentang nilai/ makna dari perbuatan seseorang terhadap pemenuhan kebutuhan hidupnya, (3) memberikan sentuhan awal terhadap pengembangan keterampilan psikomotorik, dan (4) memberikan pilihan-pilihan tindakan yang dapat memacu kreativitas.

Pendidikan kecakapan hidup umum (general life skills education) tidak mengubah sistem pendidikan dan juga tidak untuk mereduksi pendidikan hanya sebagai latihan kerja. Pendidikan yang berorientasi pada kecakapan hidup umum (general life skills education) justru 
memberikan kesempatan kepada setiap anak didik untuk meningkatkan potensinya dan memberikan peluang untuk memperoleh bekal keahlian/keterampilan. (Tim Broad Based Education 2003: 13).

Transfer general life skills terhadap siswa autisme yang diaplikasikan melalui mata pelajaran yang tersedia adalah sebuah proses interaksi antara peserta didik dengan mata pelajaran dan lingkungannya, sehingga terjadi perubahan perilaku ke arah yang lebih baik. Proses ini merupakan proses pengubahan status siswa dari lack of knowledge to knowledge. Keberhasilan transfer general life skills setidaknya ditunjukan dengan adanya perubahan sikap dan perilaku serta peningkatan status pengetahuan dari tidak tahu menjadi tahu. (Endang Purwanti 2002: 4).

Secara umum, bagi siswa non ABK maupun siswa $\mathrm{ABK}$ pembelajaran general life skills bertujuan untuk memfungsikan pendidikan sesuai dengan fitrahnya, yaitu mengembangkan potensi manusiawi peserta didik untuk dapat menghadapi perannya di masa mendatang. (Sugeng Listyo Prabowo 2010: 19).

Metode Lovaas banyak dipakai untuk menangani anak-anak autistik dikarenakan metode ini memiliki beberapa kelebihan yaitu : terstruktur (teknik mengajar yang jelas), terarah (panduan program yang dapat dijadikan acuan), terukur (keberhasilan / kegagalan dapat diketahui dengan pasti).

Adanya kejelasan dari metode Lovaas tersebut di atas, metode ini sekarang banyak dipakai sebagai intervensi dini dalam penanganan perilaku untuk anak-anak autistik di Indonesia.

\section{Tinjauan Pustaka}

\section{A. Autisme}

Istilah autisme berasal dari kata "Autos" yang berarti diri sendiri dan "isme" yang berarti suatu aliran, sehingga dapat diartikan sebagai suatu paham tertarik pada dunianya sendiri (Suryana, 2004). Autisme pertama kali ditemukan oleh Leo Kanner pada tahun 1943. Kanner mendeskripsikan gangguan ini sebagai ketidakmampuan untuk berinteraksi dengan orang lain, gangguan berbahasa yang ditunjukkan dengan penguasaan bahasa yang tertunda, echolalia, mutism, pembalikan kalimat, adanya aktivitas bermain repetitive dan stereotype, rute ingatan yang kuat dan keinginan obsesif untuk mempertahankan keteraturan di dalam lingkungannya. (Dawson \& Castelloe dalam Widihastuti, 2007).

Autisme dapat didefinisikan sebagai kondisi seseorang yang luar biasa asik dengan dirinya sendiri (Reber, 1985 dalam Trevarthendkk, 1998). Pengertian ini menunjuk pada bagaimana anak-anak autis gagal bertindak dengan minat pada orang lain, tetapi kehilangan beberapa penonjolan perilaku mereka. Ini, tidak membantu orang lain untuk memahami seperti apa dunia mereka.

Ketidakmampuan sosial meliputi suatu kegagalan untuk menggunakan kontak mata langsung untuk membangun interaksi sosial, jarang mencari orang lain untuk memperoleh kenyamanan atau afeksi, jarang memprakarsai permainan dengan orang lain dan tidak memiliki relasi dengan teman sebaya untuk berbagi minat dan emosi secara timbal balik. Selain kekurangan sosial ini, anak-anak autistik juga memperlihatkan keabnormalan komunikasi yang terfokus pada masalah penggunaan bahasa dalam rangka membangun komunikasi sosial, tidak adanya keselarasan dan kurangnya timbal 
balik, serta penggunaan bahasa yang stereotip dan berulang-ulang. Misalnya jika kita bertanya (pada anak autistik) "Apa kabar Budi?" Budi akan menjawab "Apa kabar Budi” anak-anak autistik juga juga bingung dengan kata ganti misalnya ialah ketika mereka memakai kata anda untuk aku.

\section{B. Metode Lovaas}

Ada beberapa pengertian tentang terapi Lovaas atau ABA ( Applied Behaviour) Yang digunakan untuk penanganan anak autistik.

Menurut Handoyo dalam Jessica Kingley ( $2006: 8$ ) Terapi ini sangat representatif bagi penanggulangan anak spesial dengan gejala autisme. Sebab memiliki prinsip yang terukur, terarah dan sistematis juga variasi yang diajarkan luas sehingga dapat meningkatkan keterampilan komunikasi, sosial dan motorik halus maupun kasar.

Terapi Lovaas adalah metode tatalaksana perilaku yang berkembang sejak puluhan tahun, ditemukan psikolog Amerika, Universitas California Los Angeles, Amerika Serikat, Ivar O. Lovaas (Handojo, 2008: 15)., Beliau memulai eksperimen dengan cara mengaplikasikan teori B.F. Skinner, Operant Conditioning. Di dalam teori ini disebutkan suatu pola perilaku akan menjadi mantap jika perilaku itu diperoleh si pelaku (penguat positif) karena mengakibatkan hilangnya hal-hal yang tidak diinginkan (penguat negatif). Sementara suatu perilaku tertentu akan hilang bila perilaku itu diulang terus menerus dan mengalami sesuatu yang tidak menyenangkan (hukuman) atau hilangnya hal-hal yang menyenangkan si pelaku (penghapusan).

Dari beberapa pendapat di atas maka dapat disimpulkan bahwa Metode Lovaas / Applied Behavior Analysis (ABA) merupakan metode yang mengajarkan kedisiplinan dimana pada kurikulumnya telah dimodifikasi dari aktivitas sehari- hari dan dilaksanakan secara konsisten untuk meningkatkan perilaku yang signifikan. Kepatuhan dan kontak mata merupakan kunci utama dalam penerapan metode Lovaas, tanpa penguasaan kedua kemampuan tersebut anak autisme akan sulit diajarkan aktivitas-aktivitas perilaku yang lain.

\section{Pendekatan ICARE}

Dalam penyusunan perangkat pembelajaran tiap pelajaran untuk belajar aktif, digunakan satu kerangka yang sangat sederhana, yaitu disebut ICARE. Sistem ICARE mancakup lima elemen kunci suatu pengalaman belajar yang baik, yang dapat diterapkan terhadap peserta didik. Oleh karena itu, sistem ICARE sangat baik untuk diterapkan dalam proses belajar di sekolah. ICARE adalah singkatan dari: Introduction, Connection, Application, Reflection, dan Extension.Penggunaan sistem ICARE sangat memberi peluang kepada peserta didik untuk memiliki kesempatan mengaplikasikan apa yang telah mereka pelajari dalam pelatihan. Namun juga harus diingat bahwasanya perangkat tersebut harus memenuhi aturan sesuai dengan standar proses yang terdapat dalam Permendiknas no 41 tahun 2007. Dalam Permendiknas tersebut terdapat eksplorasi, elaborasi, dan konfirmasi. Di samping itu juga memasukkan pendidikan budaya karakter bangsa dan kewirausahaan. Berikut ini dijelaskan secara rinci kerangka ICARE

\section{I $=$ Introduction (Pendahuluan)}

Pada tahap pengalaman belajar ini guru atau fasilitator menetapkan materi pelajaran kepada peserta didik. Ini harus mencakup menyiapkan peserta didik secara psikis dan fisik untuk mengikuti proses pembelajaran, penjelasan tujuan pembelajaran, dan menyampaikan 
cakupan materi serta penjelasan uraian kegiatan sesuai silabus.

\section{$\mathrm{C}=$ Connection $($ Koneksi)}

Koneksi merupakan tahap pengkaitan antara pengetahuan yang dimiliki peserta didik sebelumnya. Dalam banyak hal, proses belajar itu berurutan (sequential) dengan membangun suatu kompetensi di atas suatu kompetensi sebelumnya. Karena itu, semua pengalaman belajar yang baik harus dimulai dari apa yang peserta didik telah tahu dan dapat dilakukan serta dapat dibangun di atasnya. Pada tahap connection pembelajaran guru mencoba mengaitkan materi pembelajaran yang baru dengan pengalaman belajar sebelumnya. Guru dapat mencapainya dengan melakukan latihan brainstorming sederhana untuk mengenali apa yang telah diketahui peserta didik, dengan meminta peserta didik mengatakan kepada guru apa yang mereka ingat dari pembelajaran sebelumnya atau dengan mengembangkan suatu kegiatan yang dapat dilakukan peserta didik secara mandiri. Dengan mengikuti hal ini guru menghubungkan peserta didik dengan materi yang baru. Namun, yang perlu diperhatikan adalah bahwa tahap ini dilakukan tidak terlalu lama menghabiskan waktu. Paling lama waktu dugunakan sekitar sepuluh menit.

\section{A = Application (Penerapan)}

Aplikasi merupakan

bagian terpenting dalam pembelajaran. Setelah peserta didik memperoleh pengetahuan atau keterampilan baru melalui tahap connection, mereka perlu diberi kesempatan untuk mempraktekkan dan mengaplikasikan pengetahuan dan keterampilan itu. Bagian penerapan haruslah menjadi bagian pembelajaran yang paling lama tatkala peserta didik secara berpasangan atau berkelompok bekerja secara mandiri dibawah pengarahan guru untuk melengkapi suatu kegiatan dari kehidupan nyata atauIII. memecahkan suatu masalah kehidupan nyata dengan menggunakan informasi dan keterampilan baru yang telah dicapai.

\section{$\mathbf{R}=$ Reflection (Refleksi)}

Refleksi merupakan tahap membuat ringkasan (summary) pembelajaran di mana peserta didik mendapat kesempatan untuk merefleksikan apa yang telah dipelajari bersama dengan guru untuk menilai pencapaian dirinya terhadap materi pelajaran. Refleksi dapat dilakukan melalui diskusi kelompok dimana guru meminta peserta didik membuat presentasi atau menjelaskan apa yang telah dipelajari. Kegiatan ini pun dapat dilakukan melalui kegiatan menulis ringkasan dari apa yang telah dipelajari secara individual atau melalui kuis singkat dimana guru mengajukan pertanyaan berdasarkan materi pelajaran. Pada kegiatan ini guru perlu memberikan kesempatan kepada peserta didik mengemukakan tentang apa yang mereka telah pelajari.

\section{E $=$ Extension (Perluasan)}

Perluasan merupakan pengembangan lebih lanjut dari pembelajaran yang telah diterima oleh peserta didik dan harus dilakukan oleh mereka. Karena pembelajaran tertentu telah selesai bukan berarti bahwa semua yang telah dipelajari peserta didik otomatis dapat mereka pahami atau gunakan. Oleh karena itu, guru harus memberi kegiatan sebagai kelanjutannya. Tahap extension pembelajaran diterapkan melalui pemberian kegiatan-kegiatan yang dapat dilakukan peserta didik sebagai tindak lanjut pembelajaran untuk memperkuat (reinforce) dan memperluas pembelajaran. Di sekolah kegiatankegiatan extension dapat dijadikan sebagai pekerjaan rumah (PR). Kegiatan-kegiatan extension dapat meliputi pemberian bahan bacaan tambahan dan tugas melakukan penelitian atau latihan.

\section{Tujuan Penelitian}

Penelitian ini bertujuan untuk 
mengetahui pemanfaatan penggunaan metode Lovaas dengan pendekatan ICARE terhadap General Life Skill (Kecakapan Hidup) anak Autis. Fungsi dari metode pembelajaran adalah untuk memudahkan/membantu guru dalam mengimplementasikan kegiatan pembelajaran, anak berkebutuhan khusus (autis) merupakan individu yang berbeda dengan individu pada umumnya mereka cenderung memiliki keterlambatan baik itu sikap, psikis, mental maupu intelegensi. Oleh karena itu, dengan ada metode Lovaas yang di blendedkan dengan ICARE diharapkan mampu membantu anak Autis dalam kegiatan pembelajarannya khususnya terhadap Generale Life Skill mereka yang memang memiliki keterlambatan ataupun berbeda dengan individu pada umumnya.

\section{Manfaat Penelitian}

Dengan mengetahui cara melakukan kegiatan pembelajaran bagi anak autis akan mempermudah kegiatan pembelajaran. Dikarenakan anak autis memerlukan suatu metode dan pendekatan pembejaran yang khusus dikarenakan kondisi individu yang membutuhkan penangan khusus pula, dengan bantuan menggunakan metode Lovaas dengan pendekatan ICARE sebuah inovasi dalam pengembangan metode pembelajaran yang dimana diharapkan dapat membantu para guru dan siswa pada sekolah berkebutuhan khusus untuk kegiatan pembelajaran dalam meningkatkan kemampuan General Life Skill siswa.

1. Pengembangan program pembelajaran adalah rumusan-rumusan tentang apa yang akan dilakukan guru dan peserta didik dalam proses pembelajaran untuk mencapai tujuan, sebelum kegitan belajar mengajar yang sesungguhnya dilaksanakan.

2. Dalam penyusunan perangkat pembelajaran tiap pelajaran untuk belajar aktif, digunakan satu kerangka yang sangat sederhana, yaitu disebut ICARE.

3. Pendidikan yang berorientasi pada kecakapan hidup umum (general life skills education) justru memberikan kesempatan kepada setiap anak didik untuk meningkatkan potensinya dan memberikan peluang untuk memperoleh bekal keahlian/keterampilan.

\section{Pembahasan}

\section{A. Program Pembelajaran Metode Lovaas}

Setiap orangtua akan mengalami berbagai macam perasaan pada saat mendengar dari mulut professional bahwa anaknya mengalami gangguan perkembangan yang termasuk dalam spectrum autisme. Yang sering terjadi adalah perasaan tak percaya, marah, tak dapat menerima dengan harapan bahwa diagnosis tersebut salah, rasa shock, panik, sedih, bingung, dan lain sebagainya. Banyak yang kemudian mencari pendapat dokter lain untuk lebih mendapat kepastian mengenai diagnosis tersebut, oleh karena memang masih banyak dari kalangan profesi kedokteran pun yang belum begitu mendalami gangguan yang datu ini.

Bagi seorang dokter pun rasanya sangat berat untuk menjadi pembawa kabar buruk tersebut pada orangtua yang datang untuk berkonsultasi dengan perasaan harap-harap cemas. Namun memberi harapan semu pada orangtua penyandang autisme adalah suatu hal yang sangat merugikan bagi penyembuhan anak tersebut, sehingga tatalaksana terapi harus secepat mungkin diterakpan.

Untunglah bahwa sebagian besar orangtua dapat menerima dengan tabah kabar tersebut dan langsung mau bekerjasama untuk menerapkan 
tatalaksana penanganan autisme secara terpadu untuk anaknya.

Penanganan terpadu harus secepat mungkin dilaksanakan bila diagnosis autisme sudah terbentuk. Meskipun kelalaian yang ada di otak tidak dapat disembuhkan, namun dengan pola penanganan terpadu dan intensif, gejala-gejala autisme dapat dikurangi bahkan dihilangkan, sehingga diharapkan bisa berbaur dan hidup mandiri dalam masyarakat normal.

Dalam karya tulis ini, penulis akan memaparkan suatu jenis terapi yang terbukti efektif dalam menangani penyandang autistik secara terpadu. Terapi ini dikenal dengan Metode Lovaas atau terapi ABA ( Applied Behaviour ) Yang digunakan untuk penanganan anak autistik.

Metode Lovaas ini didasarkan pada teori "Operant Conditioning" yang dipelopir oleh Burrhus Frederic Skinner (1904-1990) seorang behavioralis dari Amerika Serikat. Dasar teori Skinner sendiri adalah pengendalian perilaku melalui manipulasi imbalan dan hukuman. Skinner percaya bahwa sebenarnya orang yang telah memberinya kunci untuk memahami perilaku adalah Ivan Pavlov, seorang fisiolog Rusia dengan teorinya Classical Conditioning. Pavlov mengatakan: kendalikanlah kondisi (lingkungan) dan kita akan melihat tatanan (order).

Modifikasi perilaku (behavior modification) ini pada mulanya merupakan cara untuk melatih hean percobaan dengan menggunakan imbalah dan hukuman secara sistematis, namun seperempat abad belakangan ini telah berkembang menjadi pendekatan ilmu pendidikan (pedagogical approach Ivar Lovaas adalah seorang psikolog klinis yang sejak tahun 1964 menggunakannya dalam upaya membantu anak-anak yang mengalami gangguan perkembangan, lalu ia mencoba menggunakan metode ini untuk melatih anak-anak autis di UCLA.

Metodenya terutama didasarkan pada pemecahan tugas-tugas, termasuk tugas yang kompleks, abstrak seperti komunikasi, dengan menggunakan bahasa menjadi serangkaian langkah secara runtun, dan setiap langkah menyiapkan jalan untuk langkah berikutnya. Mengajar dengan menggunakan "discrete trials" orangtua dan terapis bekerja sebagai tim untuk menciptakan suasana belajar yang sangat terstruktur dan konsisten. Secara berangsur-angsur, si anak tidak hanya dapat mengerti "discrete bits" dari masalah pokok yang diajarkan, tetapi lebih penting lagi untuk memfokuskan perhatian mereka, berkonsentrasi dengan lebih efektif, dan dengan itu dapat belajar dengan lebih mudah. Begitulah akhirnya mengapa metode ini juga dikenal dengan kata discrete trial training.

Sesuai dengan namanya, teknik ini berangkat dari teori behavioristik dimana mereka meyakini bahwa perilaku berhubungan dengan system reward ( hadiah / penghargaan ) dan konsekwensi ( akibat ). Berangkat dari pemahaman dasar ini maka teknik ini biasanya digunakan sebagai dasar untuk metode mengajar. Oleh sebab itu, berangkat dari teori ini, Lovaas dan The Lovaas institute mengembangkan teknik ini dan menjabarkannya menjadi beberapa pengertian di bawah ini) :

\section{a. Applied}

Meletakkan penugasan pada kondisi yang real

\section{b. Behavioral Analysis}

Observasi dan analisis yang dilakukan untuk obyek perilaku tertentu dengan tujuan untuk merubah atau menciptakan perilaku baru yang diinginkan. 
Sehingga secara ringkas dapat dikatakan bahwa Metode Lovaas adalah suatu teknik yang telah disusun secara sistematis untuk mengurangi perilaku yang tidak diinginkan dan meningkatkan perilaku yang diharapkan.

Teknik ini diberikan dengan tujuan untuk meningkatkan pemahaman dan kepatuhan anak autis terhadap aturan. Dari terapi ini hasil yang didapatkan signifikan bila mampu diterapkan secara intensif, teratur dan konsisten pada usia dini.

\section{B. Metode Lovaas Pada Anak Autis}

Sebelum memulai dengan terapi itu sendiri, orangtua dan terapis biasanya membicarakan persiapan untuk memulai terapi. Karena metode ini tidak dapat ditangani sendiri, sebaiknya suatu tim dibentuk dengan serangkaian jadwal yang akan dilalui sang anak. Dalam mengerjakan metode Lovaas anak akan dituntut waktu belajar tidak kurang dari 40 jam per/minggu, dan adanya suatu tim terapis dan orangtua yang dijadwalkan bergantian memberikan drill, dan biasanya pertemuan rutin $2-3$ minggu sekali oleh anggota tim untuk membahas segala sesuatu yang dialami bersama anak termasuk memastikan instruksi dan program yang dipakai selalu sinkron.

Secara umum, tujuan programnya adalah sebagai berikut:

1) Usaha suatu tim pengajar-para guru bekerja sama dan anak

2) Compliance (kepatuhan), misalnua duduk dan siap bila diminta

3) Mengurangi self-stimulatory dan perilaku agresif

4) Mengajarkan kemampuan menirukan secara umum

5) Setelah pra-kemampuan diajarkan, perkenalkan anak yang lain sebagai model
6) Ajarkan suatu cara untuk berkomunikasi:

a. Berbicara

b. Gambar, misalnya menggunakan COMPIC sebagai jembatan untuk nantinya berbicara menggunakan suara

c. Bahasa isyarat, biasanya tidak begitu disarankan karena kemungkinan penggunaannya sebagai cara untuk selfstimulatory. Bahasa isyarat ini juga seharusnya tidak boleh diajarkan pada anak yang masih sangat kecil (di bawah 4 tahun) yang konsep bahasanya kemungkinan terlambat, atau anak-anak yang belum banyak menerima verbal training.

7) Ajarkan anak bermain secara mandiri dan dengan anak yang lain

8) Ajarkan kemampuan pra-sekolah (misalnya menggunting, menempel dan duduk di lantai)

9) Ajarkan kemampuan bantu diri (untuk ke kamar mandi)

10) Ajarkan kemampuan bersosialisasi (misalnya menyapa "halo")

11) Ajarkan kemampuan motorik kasar dan halus

12) Ajarkan bahasa reseptif/ekspresif (kata benda, kata kerja, kemampuan memulai pembicaraan)

13) Kemampuan yang telah diajarkan kemudian digeneralisasikan ke orang-orang lain dan situasi lainnya.

Terapi wicara dan Lovaas. Koordinasi antara terapi wicara dengan program metode Lovaas antara lain:

1) Terapi wicara mengambangkan objektif untuk bicara serupa dengan program perilaku untuk mencapai generalisasi

2) Terapi wicara turut menggunakan program Discrete Trial sekomunikatif dan sefungsional mungkin 
3) Terapi wicara dapat menambahkan informasi penting tentang bicara dan bahasa

4) Terapi wicara dapat membantu memastikan bahwa semua terapis yang ada menggunakan kata, perintah dan mainan dalam mencapai tujuan tersebut

5) Terapi wicara dapat memberikan informasi kepada timnya tentang perkembangan linguistik yang wajar serta urutan komunikasi yang normal

6) Terapi wicara dapat menunjukkan bagaimana melakukan penyatuan objektif untuk kegiatan sehari-hari ataupun aktivitas harian, misalnya makan, mandi, dan waktu tidur untuk membantu generalisasi dan urutan

7) Terapi wicara dapat mengembangkan reinforcers yang dapat digunakan seperti mainan, permen, pelukan, pujian dan lainnya

8) Terapi wicara seharusnya mengevaluasi bagaimana cara keterampilan bahasa dipakai dalam lingkungan kelas untuk mendapat yang maksimum dari interaksi ini

9) Terapi wicara juga dapat membantu memecahkan masalah-masalah yang berkaitan dengan linguistic

10) Terapi wicara pun dapat membantu dalam evaluasi dan terapi untuk masalah-masalah yang ada bersamaan dengan masalah autisme yang menyangkut bicara misalnya apraxia dan lain-lain

Kurikulum untuk speech sendiri harus termasuk language technique facilitation (eyecontact, modelling, pemakaian pertanyaan langsung, misalnya “apa ini?") dan sebagainya.

\section{E. Pendekatan ICARE}

Penyusunan bahan pelajaran/sesi untuk belajar aktif, digunakan satu kerangka yang sangat sederhana, yaitu disebut ICARE. Sistem ICARE mencakup lima elemen kunci suatu pengalaman belajar yang baik, yang dapat diterapkan terhadap anak, peserta didik, orang muda maupun orang dewasa. Oleh karena itu, sistem ICARE sangat baik untuk diterapkan bukan hanya pada pelatihan di manapun dilakukan tetapi juga dalam proses belajar di sekolah. ICARE adalah singkatan dari: Introduction, Connection, Application, Reflection, dan Extension. Penggunaan sistem ICARE sangat memberi peluang kepada para peserta pelatihan atau peserta didik untuk memiliki kesempatan mengaplikasikan apa yang telah mereka pelajari dalam pelatihan. Berikut ini dijelaskan secara rinci kerangka ICARE.

\section{Tahap - Tahap Model Pembelajaran ICARE}

Model Pembelajaran ICARE meliputi 5 unsur kunci dari pengalaman pembelajaran (baik dengan anak-anak, orang muda atau orang dewasa). Sesuai dengan namanya, "ICARE" pembelajaran ini merupakan singkatan dari 5 kata yaitu: introduction (pengenalan), connection (menghubungkan), Application (menerapkan), Reflection (merefleksikan), dan Extension (memperluas dan evaluasi). Sistem pembelajaran ICARE dikembangkan oleh Department Of Educational Technology, San Diago University (SDSU) Amerika Serikat. Secara diagramatis, system pembelajaran ICARE adalah sebagai berikut:

1. Tahapan Pertama: Introduction (Pengantar/Perkenalan)

Introduction pada tahap ini guru atau fasilitator menanamkan pemahaman tentang isi dari pelajaran kepada peserta didik. Bagian ini harus berisi tujuan pelajaran dan apa yang akan dicapai selama pelajaran tersebut. Introduction harus singkat dan 
sederhana, menginformasi bahan yang hendak disajikan dengan bahan secara keseluruhan (konteks).

2. Tahap Kedua: Connection (Menghubungkan/Hubungkan)

Sebagian besar pembelajaran merupakan rangkaian dengan satu kompetensi yang dikembangkan berdasarkan kompetensi sebelumnya. Oleh karena itu, semua pengalaman yang baik perlu dimulai dari apa yang sudah diketahui, dapat dilakukan oleh peserta didik dan mengembangkannya. Sebagian besar pembelajaran merupakan rangkaian dengan satu kompetensi yang dikembangkan berdasarkan kompetensi sebelumnya, menghubungkan pengetahuan baru dengan pengetahuan sebelumnya dapat untuk meningkatkan pemahaman dan aplikasi. Pada tahap ini, yaitu : a) Membagi materi ke dalam sub-sub topic untuk memudahkan siswa memahami informasi baru; b) Menghubungkan informasi kepada tugas-tugas yang berkaitan dengan dunia nyata dan pengetahuan sebelumnya; c) Memfasilitasi siswa dengan informasi secara bertahap dan berkesinambungan sehingga merupakan rangkaian belajar yang bermakna; d) Menyajikan bahan yang diberikan secara lebih menyenangkan berbagi pendekatan dan penggunaan media.

3. Tahap Ketiga: Application (Mengaplikasikan/Menerapkan).

Tahap ini adalah yang paling penting dari pembelajaran. Setelah peserta didik memperoleh informasi atau kecakapan baru melalui tahap connection, mereka perlu diberi kesempatan untuk mempraktikkan dan menerapkan pengetahuan serta kecakapan tersebut. Bagian application harus berlangsung paling lama dari pelajaran/sesi dimana peserta bekerja sendiri, tidak dengan instruktur, secara pasangan atau dalam kelompok untuk menyelesaikan kegiatan nyata atau memecahkan masalah nyata menggunakan informasi dan kecakapan baru yang mereka peroleh. Pembelajaran dilakukan secara interaktif dan mengaplikasikan bahan yang diajarkan dengan persoalan nyata yang terjadi dalam kehidupan seharihari.

4. Tahap Keempat: Reflection (Refleksi).

Bagian ini merupakan ringkasan dari pelajaran/sesi, sedangkan peserta memiliki kesempatan untuk merefleksikan apa yang telah mereka pelajari. Tugas instruktur adalah menilai sejauh mana keberhasilan pembelajaran. Kegiatan refleksi atau ringkasan dapat melibatkan diskusi kelompok dimana instruktur meminta peserta untuk melakukan presentasi atau menjelaskan apa yang telah mereka pelajari. Mereka juga dapat melakukan kegiatan penulisan mandiri dimana peserta menulis sebuah ringkasan dari hasil pembelajaran. Refleksi ini juga bisa berbentuk kuis singkat, yaitu instruktur memberi pertanyaan berdasarkan isi pelajaran. Poin penting untuk diingat dalam refleksi adalah bahwa instruktur perlu untuk menyediakan kesempatan bagi para peserta untuk mengungkapkan apa yang telah mereka pelajari.

5. Tahap Kelima: Extension (Memperluas Dan Evaluasi).

Ada dua kegiatan utama dalam tahap akhir ini. Pertama guru melakukan serangkaian pengalaman belajar tambahan yang bisa memperkaya pengetahuan yang telah dicapai siswa. Kedua, sebagai bentuk kegiatan evaluasi, yaitu sampai sejauh mana para siswa dapat menguasai bahan yang telah diajarkan oleh guru. Di sekolah extension biasanya disebut pekerjaan rumah. Kegiatan extension 
dapat meliputi penyediaan bahan bacaan tambahan, tugas penelitian atau latihan.

\section{Kelebihan \& Keterbatasan Model ICARE}

Pembelajaran dengan model pembelajaran ICARE memlki beberapa kelebihan dan kelemahan sebagai berikut:

1. Kelebihan

a. Pemetaan struktur isi yang seimbang antara teori dan praktek bagi guru dan siswa;

b. Memiliki pendekatan berbasis life Skill

c. Memungkinkan sekolah melakukan monitoring dan evaluasi yang terbuka kepada gurunya;

d. Memberikan peluang bagi sekolah untuk memformulasikan kembali struktur kurikulum yang ada dengan kebutuhan dan karakteristik siswa serta kondisi lingkungan yang ada;

e. Memberikan kesempatan kepada guru untuk melakukan apersepsi pada setiap pembelajaran yang akandilakukan dengan mudah.

2. Keterbatasan

a. Menuntut kemampuan analisa yang menyeluruh terhadap deskripsi dan struktur kurikulum;

b. Memerlukan pemahaman guru terhadap semua panduan kebijakan implementasi kurikulum secara utuh;

c. Menuntut guru untuk selalu otomatis dalam melakukan analisa komponen model (termasuk model ICARE) berdasarkan topik materi yang akan diajarkan;

d. Menuntut sekolah dan guru dalam melakukan analisa kebutuhan dan trend pemanfaatan bidang ilmu dalam kehidupan sehari-hari oleh siswa.

\section{General Life Skill Anak Autis}

Pembelajaran general life skills terbagi menjadi dua komponen yaitu kecakapan personal dan kecakapan sosial. Dari kedua komponen tersebut pun terbagi lagi menjadi beberapa item yang menjadikan pembelajarannya bisa dikatakan mencakup apa yang dibutuhkan oleh siswa. Sebagai penjelasannya bisa dilihat bagaimana pembelajarannya yaitu:

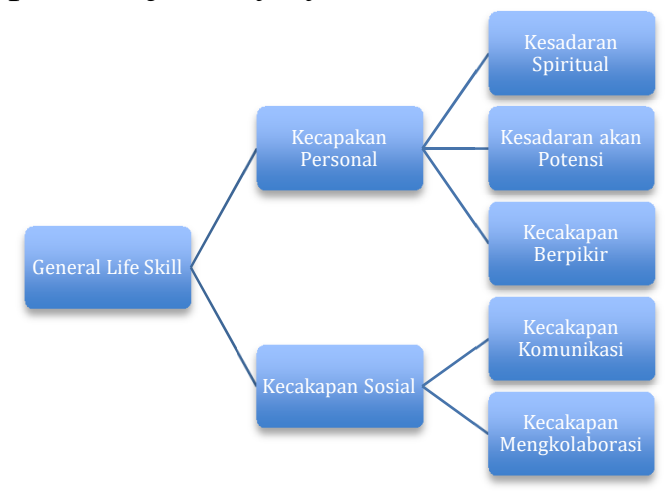

Gambar 1. Pembelajaran general life skills

Applied Behaviour Anslysis adalah suatu metode terapi tata perilaku pada anak autis yang diberikan secara intensif selama 40 jam per minggu dalam kurun waktu lebih dari 2 tahun. Metode Lovaas ini pada prinsipnya menekankan pada terapi tata perilaku anak autisme yang cenderung bersifat labil yang terkadang menunjukkan perilaku yang hiperaktif dan di waktu lain juga menunjukkan perilaku pasif/ hipoaktif. Sehingga dengan perilakunya yang labil tersebut, anak autis akan semakin merasakan kesulitan dalam bersosialisasi dengan orang lain/ lingkungannya, disamping keterbatasan kemampuan komunikasi yang dimilikinya. Diharapkan dengan terapi pengendalian perilakunya tersebut, diharapkan mampu mendorong pemulihan kembali kondisi autis yang disandangnya.

\section{a. Shaping}


Merupakan suatu proses yang dipakai untuk merubah perilaku anak $\square$ menjadi perilaku yang diharapkan. sebagai contoh: jika anak hanya belajar mengucapkan kata, lebih baik ajarkan pegang atau meminta benda, kemudian ajarkan cara menghasilkan bunyi, sebuah suku kata berikutnya bagaimana menghasilkan sebuah kata. (Rudi Sutadi 2003: 29).

b. Prompting

Prompt adalah bantuan yang sifatnya membantu anak agar siswa mampu $\square$ memberi respon benar sesuai dengan instruksi yang diberikan guru.

(D. $\square$ Prasetyono 2008: 34)

c. Fading

Cara bagaimana memecah bantuan yang diberikan kepada anak, agar anak tidak tergantung terhadap bantuan yang diberikan.

d. Chaining

Suatu kemampuan yang dipecah menjadi unit terkecil, kemudian unit$\square$ unit tadi dirangkai menjadi satu. Hal ini dapat dilakukan dari urutan depan (forward) ataupun dari belakang (backward). Contoh: mengajarkan mengatakan "saya mau kue",(forward) Katakan "saya", katakan "mau", katakan "kue", katakan "saya mau kue".

e. Penguat yang Berbeda

Membedakan antara hadiah atau penguat yang diberikan berbeda antara $\square$ respon yang diberikan bantuan dan respon yang langsung benar atau sesuai.

f. Instruksi atau SD (Discriminative Stimulus)

Instruksi yang digunakan singkat, jelas dan konsisten dan hanya diberikan satu kali. Maksudnya adalah hanya terdiri dari kata yang pendek, jelas adalah perintah sesuai dengan apa yang akan diajarkan dan hanya mengajarkan satu aktivitas pada satu saat, konsisten adalah kata yang digunakan antar guru dan keluarga, juga orang rumah harus sama persis. Instruksi diberikan dengan suara seperti sedang bicara dengan orang normal, tidak dengan terlalu keras atau membentak. Anak diberikan 3 kesempatan untuk merespon, kesempatan yang ketiga anak harus langsung dibantu bersamaan dengan SD. (Trantoro Safaria 2005: 189).

\section{g. Respon Anak (feedback)}

Ada 3 kemungkinan respon dari anak yaitu tepat, atau tidak sama sekali. $\square$ Apapun respon anak, berikan konsekuensi yang sesuai. Respon tepat diberikan hadiah berupa makanan atau pujian, respon tidak tepat atau tidak ada respon diberikan kata tidak, ada juga setengah respon benar maka akan diberikan kata coba lagi. Mengatakan tidak dengan nada yang datar bukan nada membentak untuk respon yang salah, memberikan hadiah bila respon benar berupa pujian dengan nada yang sangat gembira. Hadiah yang diberikan bila respon benar dapat berupa pujian, makanan yang disenangi atau mainan, namun demikian lama kelamaan hadiah akan dikurangi sehingga hanya ada pujian saja.

h. Generalisasi

Supaya penyandang autisme tidak hanya bisa keterampilan di ruang $\square$ terapi, maka diperlukan generalisasi di tempat yang berbeda dengan orang $\square$ yang berbeda dan materi yang berbeda.

i. Maintenance

Adalah generalisasi terus menerus. Keterampilan yang sudah dikuasai diulang kembali secara berkala supaya tidak hilang.

\section{KESIMPULAN}

Dalam hal pembelajaran yang diterapkan guru terhadap anak adalah $\square$ menggunakan metode Applied Behaviour Analysis (ABA)/ Lovaas, yang mana pelaksanaannya pun 
mengalami beberapa kendala. Sebagai contoh; usaha guru dalam merubah perilaku siswa menjadi perilaku yang diharapkan. Dalam penerapan General life skills pada metode ABA/Lovaas, penulis masih belum melihat akan kemaksimalan penerapan metode ABA/Lovaas itu sendiri, sehingga tidak semua dari komponen ABA/Lovaas dapat dilakukan. Hal inilah yang menjadikan guru harus kreatif mencari cara supaya anak dapat mengikuti setiap arahan yang diajarkan gurunya. Dalam hal ini metode ABA/Lovaas pun sebenarnya dapat berjalan dengan lancar jika guru dapat mengoptimalkan perannya secara maksimal.

Mengenai pembelajaran terhadap siswa juga menggunakan media dalam $\square$ pelaksanaannya, adapun media pembelajaran yang digunakan yaitu media audio dan visual. Sebenarnya media pembelajaran dengan menggunakan audio dan visual sangat membantu dalam proses pembelajaran terhadap siswa, akan tetapi ketika media ini diterapkan pun menemukan kesulitan dalam pelaksanaanya. Dikarenakan tidak semua siswa autis dapat menerima sistem pembelajaran dengan menggunakan media audio maupun visual, setiap anak mempunyai kapasitas kepekaan sendiri- sendiri dalam menerima pembelajaran dengan media audio maupun visual, sehingga perlu adanya kreatifitas guru dalam melihat minat dan bakat anak. Terhadap hal apa anak itu tertarik, baik media audio maupun visual. Sebagai contoh yang sangat menyukai media visual berupa gambar, di sini guru menstimulus dalam proses pembelajaran dengan media gambar yang cukup menarik.

Secara umum, bagi siswa non ABK maupun siswa ABK pembelajaran general life skills bertujuan untuk memfungsikan pendidikan sesuai dengan fitrahnya, yaitu mengembangkan potensi manusiawi peserta didik untuk dapat menghadapi perannya di masa mendatang.

\section{DAFTAR PUSTAKA}

[1] Arif, Rohman. (2009). Politik Ideologi Pendidikan. Yogyakarta: Laksbang Mediatama.

[2] Brady, L. (1990). Curriculum Development. Sydney : Prentice Hall of Australian Limited.

[3] Burden, Paul R and Byrd, David. (1999). Method for Effective Teaching. Second Edition. Boston: Allyn and Bacon

[4] Callon, JD. (1996). Competitive Advantage Through Information Technology. California : The McGraw-Hill Coimpanies, Inc.

[5] Clark, R.W. (1999). Effective Professional Development Schools. Agenda for Education in a Democracy. California ; Jossey-Bass, Inc.

[6] D. Prasetyono. (2008). Serba-Serbi Anak Autis. Yogyakarta: Diva Pres.

[7] Efendi, Mohammad. (2009). Pengantar Psikopedagogik Anak Berkelainan. Jakarta: Bumi Aksara.

[8] Jalil, Fasli dan Supriadi, Dedi. (2000). Reformasi Pendidikan dalam Menyambut Otonomi Daerah. Yogyakarta:

[9] Kementrian Pendidikan Nasional, Buku 1 Panduan Pengembangan Pendekatan Belajar Aktif, Badan 
Penelitian Dan Pengembangan Pusat Kurikulum, Jakarta, 2010, hlm.100.

[10] Krisnawati, Putu, Yuli, et.al., Penerapan Model Pembelajaran ICARE (Introduction Connection Application Reflection Extention) Untuk Meningkatkan Hasil Belajar Teknologi Informasi Dan Komunkasi (TIK) Kumpulan Artikel Mahasiswa Pendidikan Teknik Informatika (KARMAPATI) Volume 3, Nomor 1, Maret 2014, hlm.91.

[11] Levin, James \& James F. Nolan, (1993). Classroom Management. New York: Prentice Hall-Inc.

[12] Llyod, S.B., and Dugan, L. (1995). The Training and Development Sources Book. Massachusetts: HRD Press and Publication.

[13] Majid, Abdul, Belajar Dan Pembelajaran, PT Remaja Rosda Karya, Bandung, 2014, hlm.261.

[14] Resiser A. Robert \& Dick Walter.(1996). Instructional Planning : a Guide for Teacher. Boston:A Simon and Schuter Company

[15] Rogers, Everetts M. (1983). Diffusion of Innovation. New York : The Free Press.

[16] Safaria, Triantoro. (2005). Autisme Pemahaman Baru Untuk Hidup Bermakna. Yogyakarta: Graha Ilmu.

[17] Smart, Aqila. (2010). Anak Cacat Bukan Kiamat: Metode Pembelajaran dan Terapi Untuk Anak Berkebutuhan Khusus. Yogyakarta: Katahati
[18] Purwanti, Endang et all. (2002). Perkembangan Peserta Didik. Malang: UMM Press.

[19] Sutadi, Rudy et all. (2003). Penatalaksanaan Holistik Autisme, Pusat informasi dan Penerbitan Bagian Ilmu Penyakit Dalam. Jakarta: FK UI.

[20] Tim Broad Based Education (BBE) Depdiknas. (2003). Pola Pelaksanaan Pendidikan Kecakapan Hidup. Surabaya: SIC bekerjasama dengan LPM UNESA.

[21] Dinn Wahyudin, Model Pembelajaran ICARE Pada Kurikulum Mata Pelajaran TIK Di SMP, Jurnal, FIP Universitas Pendidikan Indonesia, 2010. 